\title{
The Covid-19 pandemic as a potential change agent for selected economic concepts
}

\author{
Piotr Banaszyk, Przemysław Deszczyński, Marian Gorynia, Krzysztof Malaga
}

\begin{abstract}
A B S T R A C T
Objective: The objective of the article is to refer to the thesis about the need to modify the main paradigm of economic sciences - by which we mean mainstream economics - with all its consequences that influence the whole economic sciences. We posit the need for the modification of how economic sciences are practiced in ontological, epistemological, and methodological aspects. The need results from the impact of several factors that appeared even in the pre-pandemic period, for which Covid-19 may be a complementary and reinforcing circumstance that may even directly determine the change.

Research Design \& Methods: The main method we used was that of critical literature analysis. We constructed a set of normative recommendations for changes in economic sciences. Next, we selected four issues to exemplify the areas that require change, for which we proposed a set of postulates that constitute the desired modifications in economic sciences.

Findings: The conducted literature review shows that the number of people convinced of the need to modify the assumptions and content of economic sciences grows systematically. Sometimes, there even appears a more elaborate demand for the revision of economic sciences, not only of their modification.

Implications \& Recommendations: Firstly, the most important consequence of the study is the justification of the postulate of departing from the dominance of the main paradigm of economic sciences contained in mainstream economics towards noticing the multi-paradigm character of economic sciences, and secondly, the support of the position leaning towards the active and normative involvement of economic sciences in creating/correcting the surrounding reality.

Contribution \& Value Added: The text is a synthesis of the postulates previously reported in the literature regarding the modification of economic sciences with the consequences caused by the Covid-19 pandemic. Chronologically, the Covid-19 pandemic is the last of the causative factors of the revision under consideration - neither the only nor the most important factor - but what draws attention are its direct nature, violence, and the surprise associated with its appearance.

Article type: research article

Keywords:

Covid-19 pandemic; methodology of economics; paradigm; change agent; economic the-

JEL codes: ory; homo economicus

A11, A12, B41, B50

$\begin{array}{lll}\text { Received: } 14 \text { April } 2021 & \text { Revised: } 20 \text { July } 2021 & \text { Accepted: } 22 \text { July } 2021\end{array}$
\end{abstract}

\section{Suggested citation:}

Banaszyk, P., Deszczyński, P., Gorynia, M., \& Malaga, K. (2021). The Covid-19 pandemic as a potential change agent for selected economic concepts. Entrepreneurial Business and Economics Review, 9(4), 35-50. https://doi.org/10.15678/EBER.2021.090403

\section{INTRODUCTION}

In this article, we reflect on the necessity to modify the current main paradigms in the economic sciences ${ }^{1}$, with all its consequences that influence theoretical and empirical research in economics, finance, business, management, or socio-economic geography and public management. Within the

\footnotetext{
${ }^{1}$ The term "economic sciencies" used in this article should be understood as the equivalent of the terms "economics and
} business" or "economics and management". 
economy of the real world and individual national economies, there are so many factors in favour of change that we deem it necessary to consider this issue once again. We know that we are neither the first nor the only ones to write about the matter. However, we believe that - this time - such a change requires more determination and persistence. The Covid-19 pandemic appears to be the critical factor that made the world stop - for a moment, a few months, or maybe even a few years - and it appears to some as a factor that directly prejudges the need for that change. Of course, the pandemic is not the sole determinant of the postulated re-evaluation, but it is the most recent factor among many other, and by decelerating socio-economic processes, it encourages reflection and allows time for deliberation and action. The change of the real world requires many actions in practically all spheres of human activity and on various levels. Moreover, the change requires that we include in it the sphere of science and education. In other words, the change should also concern the modification of concepts developed by science. As representatives of the economic sciences, we join the discussion on the change - its goals, foundations, mechanisms, and tools - following our belief that such a contribution can influence other spheres and levels of human activity.

To illustrate our thesis, we refer to several examples of issues, subjects, theories, concepts, and models of modern economic sciences. This choice is not predetermined and closed, while the set of problems may be extended, for which we certainly hope. However, our choice is neither voluntaristic nor accidental, as it refers to our combined scientific interests, which represent distant specializations within economic sciences. The noticeable heterogeneity of our examples intends to encourage a wide range of scholars in economic sciences to expand the scope of issues that require change in research approach. Moreover, it appears to us that the accuracy of our choice of issues has been verified by the pandemic itself, among other things, as they are visibly present in the discussion concerning Covid-19 in scientific literature and journalism and have been the subject of serious polemics in economic literature for decades. These examples are homo economicus, business performance, the essence and measurement of national wealth, and globalization. In general, we seek answers to the question: What should change in economic sciences' approach to each of the issues? The order of discussion of individual issues was based on the principle of reasoning from micro to macro and global levels of inquiry ${ }^{2}$.

We seek to provoke a debate on a wide range of significant economic subjects, which raised controversy even before the outbreak of the Covid-19 pandemic, possibly leading to the creation of an outline of a modified economic sciences' research plan. The general framework of such a program could be composed of the following research questions:

RQ1: What has changed, is changing, and will change in the real world grasped in each issue (ontology) both before, during, and after the Covid-19 pandemic?

RQ2: What has changed, is changing, and will change in our understanding of the world that is significant and cognitively investigable (epistemology) both before, during, and after the Covid-19 pandemic?

RQ3: What has changed, is changing, and will change in our methodology of cognizing this world (methodology) both before, during, and after the Covid-19 pandemic?

RQ4: Are there any premises for changing the proportions of economic sciences' functions towards a descriptive-explanatory or normative role?

The implementation of the signalled framework research program would require a reflection on the relationship between the cognitive versus normative functions of economic sciences aimed at formulating postulates about what should change in economic sciences' practice. We intend to contribute to such a research program.

\footnotetext{
2 The logic of the text is based on moving from micro problems, through meso to macro. Human nature as described by the homo economicus model can be considered a key microeconomic issue, therefore this is an initial problem. Further, the EVAbased business management practice resulting from homo economicus model of financial capital providers must lead to overexploitation of the bio-natural system, so it is another important factor for modification. At the level of economic policy, the commonly used optimization (decision) criterion in the form of GDP pc is an unambiguous source of ecological and climate problems. Finally, social factors resulting from the unfair distribution of wealth are also important.
} 
The article consists of four sections. The introduction presents the objective of the article and outlines the idea of the creation of an outline of a modified economic sciences' research plan. In the second section, we briefly describe the materials and the methods used. The third section consists of six parts: the first is devoted to the discussion of the direction of modifying the reflection about economic sciences and the second is devoted to the dispute over the descriptive-explanatory versus normative character of economic sciences. Parts three to six contain a critical diagnosis and normative considerations relating to four examples of selected economic concepts: the model of homo economicus, business performance measurement and management, the essence and measurement of national wealth, and globalization. Section four presents the most important conclusions concerning the necessity to change the way economic sciences are practiced in ontological, epistemological, and methodological aspects.

\section{RESEARCH METHODOLOGY}

Method-wise, this article critically analyses subject literature and constructs a set of normative recommendations for changes in economic sciences. In this respect this is a theory development article.

As for the materials used, the authors referred to two groups of sources. The first group concerns a critical diagnosis of the way economic sciences were practiced, both before the world financial crisis in 2008-2011, during the crisis and after it, but before the outbreak of the Covid-19 pandemic. The general conclusion of these analyses was critical of the way economic sciences were practiced in ontological, epistemological, and methodological aspects. Despite the postulates for changes, the method of conducting research in economic sciences has not changed significantly.

The second group of sources used were publications created after the outbreak of the Covid-19 pandemic, which strongly emphasize the thesis that the unfavourable processes in the functioning of our civilization have gone so far that rapid and radical changes are necessary. They concern both the practice of economic activity and the way of practicing economic sciences. During the preparation of the article, we mainly used English-language literature.

In summary, our intention is that this text should be treated as a study of literature leading to the formulation of proposals for changes in economic sciences.

\section{LITERATURE REVIEW AND THEORY DEVELOPMENT}

\section{The direction of modifying the reflection about economic sciences}

Economic sciences may be considered within a set of disciplines called instrumental (Popper, 1963). The global or national economy is simply too complex and dynamic to be explained definitively once and for all. Changes in the economic behaviour of major economic players and the infrastructure they use are rapid, so it is surprising that some people promote the belief that there is one main and universal paradigm in economic sciences. Instead, economic sciences are multi-paradigmatic by nature. Fiedor (2019) indicates that the same notion was used to describe the achievements of 'mainstream' economics, without any reference to alternative economic schools. A similar position was presented by Gorynia (2019a), who applies the notion of a multi-paradigmatic approach to the entire economic sciences. It is possible that instead of seeking one or more universal paradigms of economic sciences, we should assume that the pattern for conducting research in economic sciences emerges from a permanent discussion among the subjects of this research. The sensible result of the discourse of economics should be ensured by the goodwill of speakers and the logic of content that they present. After all, contradictions in the promoted ideas can be a source of inspiration for new ideas.

Meanwhile, 'mainstream' economics dominates the economic sciences, and the limits of this current are ambiguous. Some postulate this term should be attributed in sociological perspective to the achievements of 'elite' economists, i.e. the most acclaimed scientists who work at the best universities. A more rigorous term is 'economic orthodoxy' identified for intellectual reasons and now associated with the neoclassical school in economics (Colander, 2003, p. 5). Its most important assumptions include a) common microeconomic rationality explained by the homo economicus model, b) tendency to general and partial equilibrium, c) mathematical formalism (Fiedor, 2019, p. 49). Therefore, the 
characteristic of core research presented by Fiedor refers to economic orthodoxy and is one of the components of mainstream economics. However, this component is very expansive and is responsible for 'economic imperialism,' i.e. the pursuit of imposing exclusive correctness on other schools of thought, other scientific disciplines, and even the extra-scientific practice of human activities (Davis, 2006, pp. 7-8). Nevertheless, this orthodox thought - along with the neo-Keynesian school of thought, among other approaches - forms the basis of the proposal of the 'new neoclassical synthesis,' which we can now treat from a sociological perspective precisely as a mainstream concept.

According to some, mainstream economics justifies and is responsible for the devastation of the natural environment and the often-encountered separation of economic rationality from ethical and moral imponderables. The proponents of mainstream economics even secured for themselves institutional support for the promotion of their ideas around the world in the form of the Washington Consensus as an instruction of conduct for the officers of the International Monetary Fund and the World Bank. As a result, what counts around the world is the continuous increase in production (e.g. measured by the dynamics of gross domestic product, or GDP) and providing investors with ever more added value (e.g. measured by economic value added, or EVA), which require growing consumption (now in the stage of excessive consumerism). In other words, when recording these effects, we should indicate the frequently encountered overexploitation of natural resources (as the basis for production) and often uncritical search for the cheapest locations of production plants (to multiply profits), along with confusing aggressive marketing (which deprives consumers of the right to the freedom of choice).

The number of people convinced of the need to modify the assumptions and content of economic sciences grows systematically (The Economist, 2020; Coyle, 2020; Skidelski, 2020). Sometimes, there even appears a more elaborate demand for the revision of economic sciences. We argue that - in order to make progress in the matter - the essence of modification/revision of economic sciences should be evaluated and changed in the spirit of kindness and awareness of the value of scientific achievements to date.

Chronologically, the Covid-19 pandemic is the last of the causative factors of the revision under consideration - neither the only nor the most important factor - but what draws attention are its direct nature, violence, and the surprise associated with its appearance.

At this point, let us focus on several features of the Covid-19 pandemic that determine the specificity of its impact on the socioeconomic system and the crisis phenomena characteristics that it engendered. Firstly, the pandemic has all the characteristics of a 'black swan' event, i.e. an unexpected and unlikely event but one with enormous consequences (Taleb, 2010; Roubini, 2020a). Secondly, the nature of the crisis caused by the pandemic as a non-economic phenomenon concerns the supply, demand, and financial spheres, so it can be the subject of interest for all areas of economic sciences, which we notice in the number and scope of ongoing research projects and the already published output. Thirdly, the most important features of the crisis are its violent course, deep recession, and the significant decrease in global GDP, employment, and other indicators; not to mention the industry-sectoral and spatial diversification (Roubini, 2020b). We find ourselves amid the deepest peacetime recession in the last 150 years, which has already had a devastating impact on the world economy (Wolf, 2020). Fourthly, counteracting the negative economic impact of the pandemic has led to unprecedented interventions by governments and international organizations (IMF, 2020). Fifthly, we must indicate the difficulties in forecasting the postcrisis future and the rebuilding of the world economy, characterized by very diverse forecasts and the need for their systematic updates (Wolf, 2020). These uncertainties and dilemmas seem to indicate a great need for reflection of all economic sciences' areas, which may contribute to building a 'new normality' free from past mistakes in economic development.

As a result of the Covid-19 pandemic - but not limited to that - the dangers related to the overexploitation of our planet's resources have not only been revealed but also acknowledged. On the other hand, there currently emerges good social atmosphere that encourages changes. The destruction of the natural environment results directly from excessive production and consumption and indirectly from the logic of market economy, while the deepest causes of this process are cultural. The social climate for modification/revision manifests in many spontaneous protest movements. 
Therefore, it is worthwhile to discuss this matter right now as the passage of time and socioeconomic processes dilute what is stagnant and immobile.

\section{The descriptive-explanatory versus normative character of economic sciences}

A matter frequently raised in discussions concerning the crisis caused by the Covid-19 pandemic is the character of economics and, more broadly, economic sciences in terms of the functions they perform. The result of centuries of reflection on this issue brought no unequivocal solutions. We can distinguish two different positions in this regard: a) a position that promotes a positive approach, b) a position that leans towards the active and normative involvement of economic sciences in creating/fixing reality.

The positive approach primarily assigns economic sciences with the descriptive-explanatory function. In this view, science should be devoid of evaluative and normative elements. One of the precursors of such an understanding of the function of science may be considered David Hume, who stated that we should not derive value judgments from descriptive judgments of facts, which is called Hume's guillotine (Hume, 1969, p. 469). Robbins (1932) and Friedman (1953) shared this view. The knowledge of how reality works may be useful at most for forecasting - i.e. predicting the future - but it should not be used for reality's creation in the sense of setting goals. However, it is hard to resist the impression that one cannot fully defend such an approach. If descriptive and explanatory knowledge show that the use of certain tools of economic policy are highly likely to lead to negatively assessed effects, then such knowledge results in a recommendation not to use these tools. Notwithstanding, this is a different situation than creating goals for socioeconomic development, and in this sense, it appears to fall within the framework that Lionel Robbins envisaged for economic sciences. Setting goals and selecting methods or means to achieve these goals are two different things.

The normative approach recommends a broader range of using economic sciences - both for setting development goals and defining the means to achieve them (Krugman, 2020). In this case, Max Weber's notion of rational action, in which the adoption of a particular intention is accompanied by the selection of means and consideration of side effects. A contemporary version of this approach is notion of new pragmatism.

In discussions about the post-Covid-19 economy, experts emphasize the need for a broader use of scientific achievements - including economic sciences - to shape reality in such a way as to minimize the likelihood of similar pandemics and crises they cause. Some indicate that the accumulation of factors negatively affecting the development of human civilization has reached unprecedented proportions, and this alone justifies the need for the use of science to rationalize civilization. Indeed, in reality the range of problems that require a solution is very wide, which we will signal below. Their cognition and explanation are essential as it is on them that the economic sciences research efforts should focus in the ontological-epistemological sense. In the sphere of ontology and epistemology, the great complexity and intricacy of relationships among components of civilization requires a comprehensive, holistic, and multidimensional approach. In this view, we should broaden the scope of empirical research to explain economic reality, especially in the area of modern civilization's shortcomings and the resulting crises. The sphere of methodology requires us to adopt a pragmatic approach, oriented towards solving specific problems, whose essence should be the focus of researchers' attention, without fixed assumptions that characterize specific schools of philosophy and dependence on a particular class of methods (Creshwell \& Creshwell, 2018). In other words, we recommend eclecticism and pluralism in the individual choice of methods. Such understood, pragmatism remains open to various visions of the studied world, diverse research assumptions, and various forms of data collection and analysis. Therefore, we may expect an increase in the role of methodological triangulation, which implies a parallel flexible use of research methods that should complement each other and contribute to the better recognition of cause-and-effect relationships in economic activity.

However, let us highlight the troublesome limitations of economic sciences. First limitation regards their multi-paradigmatic character, namely the coexistence of various notions, which some interpret as evidence of the underdevelopment of these sciences, while others as an expression of the complexity of the socioeconomic system (Gorynia, 2019a). The second limitation is related to 
the fact that the economic aspect is only one of the many dimensions of civilization, so its understanding and recommendations' construction in relation to practice should be multidimensional, considering the entirety of systemic properties. The third and final limitation is the difficulty of building economic forecasts based on theory, as signalled by e.g. Popper, Morgenstern, Lucas, or Merton. These difficulties may be viewed as premises for a constructive exchange of ideas among different schools of economic sciences and even among various disciplines or fields of study.

Thus, on the one hand, the demand for socioeconomic practice in economic knowledge necessary for the rationalization of civilization seems to be high and increased as a result of the pandemic. However, on the other hand, what hinders the rationalization of civilization is the influencing of economic reality with the use of ambiguous results of theoretical and practical research, many of which are objective in nature. In this situation, it seems to us that what may be a useful measure is even the most basic education of societies in the cardinal and unquestionable rudimentary mechanisms of economic life. We might risk a statement that changes in science should necessarily be accompanied by changes in education. Indeed, the former is not enough. In general, we may recommend that - in the face of pluralism and imperfections in created notions - we should follow a heterodox rather than an orthodox approach in education.

\section{The model of a homo economicus}

Several centuries in the evolution of the economic man construct has not led to the development of a uniform and coherent concept of both economic and extra-economic human behaviour. Various schools of economics present very different approaches to the matter by assuming 'that the goal of the economic man is the maximization of wealth, profit, utility, or preference, by which they can pursue such a goal in a rational manner' (Dzionek-Kozłowska, 2018, p. 8). In the above definition, we may identify two elements: the element of egoism and the element of rationality (optimization). The definitions of each are also ambiguous. It seems that regarding both these elements a broad compromise is possible among different positions, one that shows the usefulness of this construct in various economic theories. Simultaneously, this usefulness may be seen from the viewpoint of its two different roles: the description of the economic system and the modelling of market behaviours (North, 1990, p. 17).

As far as the element of egoism is concerned, we should note that when building the above compromise - even with a literal pejorative understanding of egoism - most economic theorists did not assume it to be the only motive of human economic activity, let alone the only motive of all human activity. Even the proponents of forming an 'economic theory of everything' based on the homo economicus model would not argue that humans pursue rational utility maximization. These scholars only assume that people behave as if they were driven by such a motive (Becker, 1976). In this context, the notion of utility seems particularly useful, as it may be defined so broadly as to include other motives for human activity.

The element of rationality (optimization) may be approached in a similar compromise manner. Representatives of many economic schools - generally, most heterodox schools - rightly reject full rationality as a descriptive and explanatory notion of human action, which is particularly emphasized by representatives of behavioural economics. The minimum condition for a compromise, then, seems to be the recognition of human rationality's limitations and imperfections. Nevertheless, the usefulness of the construct itself may be considered an idealized model or an ideal type - after Max Weber - to be used for comparisons among real human behaviours.

It seems that even before the Covid-19 pandemic, economic sciences quite unanimously moved away from the extreme and strict homo economicus model as the maximization of preferences and full rationality typical of mainstream economics. By contrast, it does not appear that Covid-19 will lead to any significant change in this situation. However, some modification in the understanding and use of the economic man model should occur. The pandemic is likely to influence the necessity to redefine the homo economicus model so as to include ontologically relevant factors that affect utility and human preferences, such as health safety, health care expenditures, disease prevention efforts, or more broadly, investment in public goods, the reliability of supply, the location of production near markets, and the understanding of the role of inventories. This does not mean that the homo economicus model's framework was too tight that these factors could not have been included in the past. There was simply no need for 
it or, more precisely, people saw no need for such an inclusion. However, in the Covid-19 and post-Covid19 reality, adding new elements to the explanans of the economic man model seems indispensable. The changes occurring in the real world (ontology) should be recognized in the sphere of cognition (epistemology) and taken into account in the construction of adequate research methods (methodology).

Let us note that observing the behaviour of people in difficult life situations caused by the Covid19 pandemic - suffice it to consider the difficult access to medicines, medical equipment, and food and hygiene resources or the greed of some entrepreneurs and cases of fraud - it seems that these conditions elevated the tendency towards selfish behaviour, which would indicate a significant descriptive role of the model widely criticized for its unrealistic nature. In turn, the concept of homo economicus does not seem to have become more attractive in the normative view because of psychological and social processes triggered by the pandemic.

We may argue that a desirable and recommended evolution of this notion can be legitimately named homo economicus moralis, which would mean the inclusion of ethical, ecological, or anti-poverty economic values and inequalities among the criteria shaping human behaviour ${ }^{3}$. In particular, what should be stressed is the impact of the pandemic on increasing the probability of rising inequality levels, which was the subject of a lively discussion even before the appearance of Covid-19 (Boushey, Delong \& Steinbaum, 2017) and is a frequently raised topic during the pandemic (Sandbu, 2020). This expected and recommended shift in focus on the capturing and exploring of the construct of economic man is part of the broader call for a shift in the practice of economic sciences in ontological-epistemological and methodological terms that we develop in this text.

\section{Business performance measurement and management}

An important element of the body of practice and theory of economic sciences is the collection of business performance management principles and techniques. Over time, this knowledge has been improved, taught at universities, and promoted by numerous consulting companies. Its development can be divided into three stages. The first one, oldest and precursory, is the view from the turn of the nineteenth and twentieth centuries, which consists in applying financial accounting criteria (e.g. return on investment, or ROE, and earnings per share, or EPS). From around 1920s to 1970s, there were attempts to broaden the reception of applied economic indicators by including non-financial measures (e.g. the French Tableau de Bord). Since the 1970s, many conceptual proposals have been made with approaches that combine strategic or qualitative achievements with financial results (activity based costing, or ABC, balanced scorecard, or BSC, time based line, or TBL) (Yadav, Sushil, \& Sagal, 2013, pp. 949-950).

However, the most widespread view regarding the desired measure of corporate management efficiency is the maximization of shareholder value, i.e. that of the owners whose capital finances company activities. The perspective of shareholder value assumes that the providers of capital finance the establishment and operation of a company, bearing a high economic risk. By providing financial resources, they expect to be adequately rewarded for their monetary contribution. Economic value added is the difference between the operating profit achieved and the cost of capital engaged in the company (Brilman, 2004). Unfortunately, the described process has triggered the so-called pursuit of undue profitability (Stiglitz, 2002), which in turn has become the source of negative economic externalities' intensification. One of these effects is the growing sanitary risk.

As early as in 1999, Neely (1999, pp. 205-228) called for a revolution in business performance management. Unfortunately, this revolution has not been implemented to a satisfactory degree to this day. Some experts emphasize that keeping with the current principles and methods will lead to a disaster. This is because maximizing EVA leads to a permanent increase in profit, which in the conditions of hypercompetition (D'Aveni, 1995) requires an equally permanent increase in sales, which is possible only thanks to intensive marketing campaigns encouraging excessive consumption. In turn, negative economic externalities cause growing social costs. These costs should be included in the reception field of measuring enterprises' business performance.

\footnotetext{
${ }^{3}$ It is worth mentioning other concepts that are under discussion in the economic sciences like: homo reciprocans, homo cooperativus, homo sociologicus, homo ecologicus/sustinens, homo hedonicus or homo urbanicus.
} 
Therefore, a change in the approach to measuring business performance of firms should result from the following circumstances. (1) The changing realities that after all constitute the subject of research in economic sciences. Due to the recent economic shock, the realized negative externalities force many to evaluate the business performance of any economic entity differently than they did in the past. Maintaining a company's human resources capacity involves an appreciation of the sanitary and work health and safety areas. The defence and expansion of market share requires reacting more quickly to demand volatility. These are ontic determinants of desired innovations. (2) Many of the determinants of required research modification in economic sciences were not identified and properly appreciated in the past. The pandemic might be understood as a catalyst for a qualitative change in the perception of the horror of the disaster impending for all of humanity. This essentially epistemic shift is proved e.g. by the view expressed in a McKinsey Institute report (Manyika, Pinkus, \& Tiun, 2020), which states that the need for capitalism reform is recognized by economists and business leaders, as reflected in the American Business Council's declaration to define the purpose of the corporation differently: as moving beyond serving shareholders and towards obligations to all stakeholders. Thus, such an approach more clearly recognizes the complexity of the relationship between the economy, the society, nature, and climate. (3) Thus, the research stream called business performance management transforms its postulated methods of managerial decision-making. These have a methodical character.

We might believe that - over time - economic resilience will become a more common system of measuring business performance. The literature defines the term 'resilience' in various ways (Bharma et al., 2011, pp. 5379-5380). Seemingly the most accurate definition of all states that resilience is the fundamental competence to respond efficiently to significant changes that disrupt the achievement of adopted plans without falling into long periods of crisis. Economic resilience should comprise three main components: productivity, security, and agility. Productivity refers to the relationship between the volume of output sold and the number of resources consumed to produce that output. Security refers to sanitary protection and ergonomic working conditions as studies show that companies that protect workplaces and workers have smaller stock market declines compared to firms that do not (Herma-Fox, LaPerla, Serafeim, \& Wang, 2020, p. 16). Finally, agility is the flexibility to adapt to changing demand requirements.

Agility and security rates are constrained by the productivity rate, which ensures at least exceeding the break-even point in business activity. Thus, it is impossible to positively evaluate a company's business activity that results in losses. At the same time, taking into consideration security and agility allows for moving away from serving only the owners of financial capital towards fulfilling obligations to all stakeholders.

\section{The essence and measurement of national wealth}

One of the most important demarcation lines between our ignorance and knowledge of economic phenomena and processes is determined by the state of the development of theory and empirical applications of statistics. These two allow us to interpret the essence and measure of the wealth of nations. For several decades now, the literature on economics and statistics continues a critical discussion on the role of GDP and derived measures in macroeconomic analyses. With GDP we measure the aggregate value of production streams of goods and services produced typically during one calendar year in a country. Thus, GDP is an average measure that allows us to evaluate in a general way the condition of different economies or their evolution over time, but it does not allow us to explain the causes and extent of social inequalities or their evolution over time.

We must remember that GDP is calculated based on data declared by economic agents. Thus, its calculation generally ignores unpaid work (e.g. housework), voluntary work, own production or consumption, monetized but undeclared production, work in the grey economy, undeclared work, billed but unneeded or unused services, environment's devastation in local, regional, and global dimensions, natural resources and the degree of their depletion, the impact of natural disasters, wars, and debts from taking unpayable loans. As a quantitative measure, GDP neglects many important social phenomena or processes of a qualitative nature such as well-being, leisure, safety, the level of education, innovative- 
ness, new technologies' productivity, various types of freedom guaranteed by democratic states, governance efficiency, public institutions' effectiveness, and respect for legal orders ${ }^{4}$. In contrast, GDP does account for the streams of products and services related to activities that are unacceptable for health, ethical, or cultural reasons such as drug trafficking, prostitution, the development of production technologies harmful to the environment, production activities associated with excessive emissions of carbon dioxide and other types of pollutants that adversely affect the global climate, along with the arms race and the excessive development of the arms industry. These lists irresistibly pose the following question: Should we continue to privilege such an imperfect measure? After all, GDP includes phenomena that worsen the condition of societies and lacks some of those that improve this condition. From the viewpoint of ontology and epistemology, it is logical to conclude that economists focus their attention on only some realities and ignore other important processes and phenomena.

Admittedly, economists are aware of the limitations that arise from the practical applications of GDP and derivative measures, ${ }^{5}$ so there is an ongoing discussion and work on the construction of new measures of socioeconomic development that would better recognize them and give a more appropriate basis for economic policies, thus ensuring a higher quality of life, environment, and health care systems, while accounting for the elimination of negative climate change causes, the more rational use of limited natural resources, non-invasive sources of energy, and improvements in the quality of human and social capital resources in relation to heterogeneous economic entities and economies. The above is clearly evidenced by the studies of international expert groups such as the report of the Commission in the Measurement of Economic Performance and Social Progress (Stiglitz, Sen, \& Fitoussi, 2009), the report of the High-Level Expert Group on the Measurement of Economic Performance and Social Progress (Stiglitz, Fitoussi, \& Durand, 2018), or the UN resolution on 'Sustainable Development Goals' from 2015. The latter identifies as many as 169 sustainable or balanced development goals with more than 200 indicators for global monitoring that jointly provide sufficient background material for a discussion on the essence and rational ways to measure the wealth of nations identified more with socioeconomic development in the world than with economic growth. The need to construct new indicators of growth and socioeconomic development is a serious challenge for scientific and research communities and statistical institutions that respect the highest methodological and ethical standards. According to van der Bergh and Antal (2011, pp. 9-10), there is currently no perfect indicator of social well-being, so economists have a serious task to perform.

The recognition of previously neglected economic processes (the ontological-epistemological aspect) and the development and dissemination of new measures of national wealth should be seen (the methodological aspect) as a necessary adaptation to new trends that emerge in economic thought. An example of such a trend beyond the economic sphere is the Covid-19 pandemic and its socioeconomic consequences. Phenomena or processes of this type - which have a very large impact on how contemporary economies or societies function - should be of particular interest to public statistics. Even if only so that all rational activities of mankind in this area of global needs effectively eliminate ignorance or negative and irrational social behaviour. This particularly concerns the due registration of the impact of Covid-19 on the resources and quality of human and social capital, the resources and functioning of labour markets, the demographic potential of individual countries, and the quality and manner of the

\footnotetext{
${ }^{4}$ First, GDP does not capture the broad range of outcomes that matter to people and contribute to their well-being. These elements are material and non-material in nature: they include income and jobs, but also health, education, work-life balance and social connections. Secondly, GDP ignores the distribution of well-being outcomes across society, as statistical averages mask important disparities between different individuals, households or groups. Thirdly, GDP alone does not provide a sufficient understanding of the role played by different drivers of economic growth and the way in which they interact to sustain growth over the long-term (Nozal, Martin \& Murtin 2019, p. 12).

${ }^{5}$ One evidence for this is that in the late 1980s, following the initiative of Daly and Cobb Jr (1989), efforts were made to develop alternative national income accounting systems aimed at determining the "Green" GDP as a competing measure of well-being and sustainable development to GDP. Examples of such measures are the Index of Sustainable Economic Welfare (ISEW) and the Genuine Progress Index (GPI). Unfortunately, despite their implementation and encouraging results, neither measure has so far reduced the importance of GDP in economic analysis. This negative conclusion is confirmed by the fact that in the assessment of the impact of the Covid-19 pandemic by political circles and the media, significant declines in GDP continue to be assigned key importance, including for the first time since the beginning of political transition in the 1990s in Poland.
} 
reorganization of systems of education, social welfare, and health care ${ }^{6}$. Such a registration can be achieved, among other things, through the tackling of latest challenges: the equalizing of economic phenomena and processes measurement frequency in the real and nominal spheres of the economy (which has never been so close to realization thanks to the development of information technologies); the bolder, fuller, and more rational use of the latest information and communication technologies (closely related to the implementation of the 4.0 economy model); the redefinition of the wealth of nations concept away from the notion of economic growth and in favour of the category of sustainable socioeconomic development; ${ }^{7}$ and finally, the continued construction of unified growth and socioeconomic development theories.

\section{Globalization}

In the economic sense, globalization (mundialization) may be treated as a special case of the internationalization of economic cooperation, characterized by the following features: a) in its essence, globalization is a logical consequence of the existing development of market economy and a natural stage of its evolution, which means it is immanent and unavoidable; b) the intensity, universality (global reach), uniformity, unification, and standardization of actions on a world scale are the basic attributes of the globalization participants; c) globalization is a higher (the highest?) stage of internationalization; d) the most important manifestations of globalization are international trade (exports, imports), foreign direct investments, international financial (capital) markets, with the role in this process played by information technology and the Internet (Gorynia, 2019b).

Noteworthy, there are large discrepancies in the understanding of globalization, especially the possible perceptions of globalization in the category of opportunities, threats, and its effects. From this viewpoint, the extensive literature on the subject (Al-Rodhan \& Stoudmann, 2006; Kowalski, 2013) reveals four basic attitudes in the understanding of globalization: an approach dominated by enthusiasm slightly cooled by reason that can be described as pro-globalization or affirming globalization (but not blindly) (Bhagwati, 2004); an approach of concerned reflexivity, characterized by the balanced understanding of the nature of globalization (Streeten, 2001); an approach imbued with a high degree of suspicion, strongly critical but without outright negation (Stiglitz, 2002); an approach that involves questioning the meaning of globalization, manifested in ideas and policies described as new protectionism and new nationalism (e.g. the actions of President Donald Trump's administration and of similar leaders; Rodrik, 2017).

From the perspective of Poland, we should note that economic globalization intensified after the fall of the Iron Curtain. From an economic standpoint, it meant the liberalization of international economic and political relations and the opening of the opportunities for the integration of previously independent markets of goods, capital, and labour into a single global market. As time passed, not only the benefits of globalization were becoming clear but also its negative effects. Stiglitz (2002) highlights such negative features of globalization as unfair rules of the game imposed by the more powerful developed countries, the uneven distribution of globalization benefits, losses of some participants in the process, imposing of an economic system inappropriate for the traditions, culture, and developmental challenges of many developing countries. Some studies even indicate that economically developed countries gain more than they lose from economic globalization, while developing countries lose rather than gain (Deszczyński, 2009).

The reputation of globalization was further undermined by emerging crises. Existing solutions were perceived as dogmatic and incapable of resolving emerging conflicts on internal and international levels. Many progressively lost faith in the reliability of neoliberal solutions in the spheres of economics (the undermining of the Washington Consensus) and politics (the functioning of liberal democracy) (Stiglitz, 2002; Rodrik, 2011; 2017).

\footnotetext{
${ }^{6}$ Examples of such efforts include: (Varshney \& Socher 2020).

7 This is supported by Hall \& Day Jr. (2009) who assess the projections for the world economy presented in the so-called Rome Report, The Limits to Growth (1972).
} 
One of the consequences of the global financial crisis of 2007-2011 was the emergence of symptoms of a process described as 'slowbalization' (meaning slow globalization; The Economist 2019). The process of deglobalization thus occurred before the Covid-19 pandemic (Gorynia, 2021). The difference resides in the new element of fear that future highly probable pathogens may cause rapidly spreading incurable diseases, which makes many expect the petrification of the deglobalization tendency in all the spheres that are synonymous with the broadly understood security of the state and its citizens. Considering the above, there must happen a redefinition of economic efficiency from short-term to long-term, and the abandonment of low prices primacy and the ensuing lack of diversified supply. What best exemplifies these matters are the problems with purchasing and manufacturing medicines in Europe, even before the outbreak of the pandemic, and then after the appearance of the coronavirus on the continent, ranging from simple personal protection equipment through disinfectants to specialized equipment such as medical ventilators. However, it remains an open question how deep the deglobalization will be and whether the opponents of neoliberal solutions in economic, political, and social systems would not want to take advantage of this objective situation to introduce and, perhaps, even impose their preferred solutions, motivated only by subjective and axiological rather than pragmatic considerations? This, however, appears to us as a rather a rhetorical question.

When it comes to the projected consequences of the Covid-19 pandemic in the sphere of globalization and the balance of economic power in the world, we encounter a plethora of views in the literature, which encourages various authors to build possible scenarios for the future of globalization (Gorynia, 2021). On the one hand, some indicate that, generally, China is recovering from the pandemic relatively better than the USA, because it has managed to avoid a recession and is rapidly returning to the path of above-average growth. On the other hand, others remark that China's role as the factory of the world may diminish. This is important because with the passage of time, there increases the probability of social unrest in China and, in consequence, a socioeconomic and political crisis. If this were to happen, it would have a disastrous impact on the global economy, given the current high dependence on Chinese supplies. If the pessimistic scenario comes true, the geography of globalization will change.

From an ontological perspective, the caesura of the Covid-19 pandemic may serve as a starting point for a change in the essence of economic processes. This change consists in the diminishing of the role of an important factor that intensifies economic globalization: consumption. Its increasing degree - often stimulated by marketing instruments - suctioned production and, in consequence, accelerated natural resources depletion, the natural environment pollution, and climate warming processes. It is possible, and at the same time advisable, that the change that now happens will lead to the abandonment - or at least limitation in scope - of the economy based on consumerism and to the transition to a closed loop economy. As the nature of management changes, what also changes is how we perceive and evaluate management (epistemological aspect). Economic globalization should respect the requirements of the closed circulation of resources, goods, and waste. There arises a need for a new analysis and critical evaluation of systems of production of consumer and investment goods around the world. Moreover, we should probably study the efficiency of economic units and the wealth of nations in a different manner (the methodological aspect). Therefore, the indicated circumstances should imply shifts both in the subject of economic sciences' research interests and in the methodology of scientific research. These are extremely important, current, and real challenges for economic sciences.

\section{CONCLUSIONS}

With this article, we intended to indicate the need for a serious reflection on the contents of economic sciences. Our reflection assumes only outlining problems and sketching argumentations that justify the change/revision in approach and content of these sciences. Real economic processes, economic policy, and business management methods prove since long that our civilization seems to be heading for a dead end. The wall with which humanity is about to painfully collide already appeared at the turn of the century with the dot-com bubble, the 2008 global financial crisis, repeated social protests against the growing stratification of income and wealth, increasingly frequent natural disasters resulting from the devastation of the environment and global warming, and now the global economic crisis 
provoked by the Covid-19 pandemic. Crises often stimulate new ideas and falsify old views. Mainstream economics and the management principles and guidelines derived from it at the global, macro, meso, and micro levels prove not fully effective. Therefore, it is reasonable to ask what and why should change in the area for which economists are responsible?

The above overview and discussion lead us to conclusions that are only signal the necessary reflection. Nevertheless, changes in economic practice and policy have already been announced (the ontological aspect), fundamental values and principles of management and the possibilities of their scientific cognition are perceived differently (the epistemological aspect), and there appear new demands of methods in economic activity research (the methodological aspect). First, we advocate cooperation between science, politics, and business, and we oppose the cynical use of each other to justify arbitrary views and pursue particularist interests. This will allow for the ideological neutrality of economic sciences and - in the long run - the strengthening of its prestige. Second, we propose posit that it is untenable to refer in the axiological sphere to the consequences of perceiving each person as homo economicus, especially in the radical version of the notion. Of course, elements of rationality and egoism are probably inherent attributes of humanity, but at the same time they cannot and should not be denied the characteristic of responsibility. Third, we prompt the inclusion of ethical values in the set of management imponderables. The problem of including these values in the standard model of rational choice has long been discussed among economists. There appear postulates to develop a model of homo economicus moralis not so much by supplementing the concept of rational choice but by its significant modification e.g. with the concept of rational compliance with norms or the concept of meta-ranking of preferences. The understanding and postulates of economic sciences towards the practice of business management should finally be liberated from the influence of at least some ideas of economic orthodoxy. In particular, the evaluation of top management's performance should cease to exclusively rely on the philosophy of managing on behalf of shareholders and with EVA. The vicious cycle of pursuing ever greater wealth for owners through ever greater production driven by excessive consumption should be broken if ecological, climatic, and civilizational risks are taken seriously. Many aptly believe that it is reasonable to include factors related to security and business agility in such an evaluation system. A consequence of accounting for business management agility with the EVA measure resides also in the drive to build extremely distributed and modularized international supply chains or, more broadly, specialize in international economic cooperation. Security requires reconsidering the validity of such a practice. We mean here not only security in the sense of ensuring economic continuity but also security in the sense of protecting nature and the climate. Economists must urgently coordinate international - or, rather, global - regulations concerning not only the above issues but also labour law, social security, education, or environmental protection. Jointly, these issues demand a different approach to the concepts of shaping the competitiveness of both nations and companies. In addition to the already developed mechanisms of competitiveness in the form of sectoral adjustments and the creation of innovation, it seems only reasonable to account for cultural mechanism. Economists usually cannot break away from the equilibrium metaphor as an instrument for explaining and deriving recommendations for economic processes. Of course, equilibrium can be a useful heuristic tool in economics deliberations, but other metaphors that illuminate the studied phenomena from different angles - and thus enrich the methodical workshop and knowledge of economic sciences representatives - should not be overlooked. An even more serious problem is the search for the correct measure of national wealth. So far, the commonly used measure is GDP, which is known to have a plethora of imperfections. The argument that nothing better has been invented so far is difficult to accept. After all, many alternative solutions have already appeared in this field, and they should finally be considered seriously. Another topic for discussion is the economic meaning of globalization. Gathered experiences show that globalization is not just a source of benefits. Theorists should conceptually confront the emerging processes of deglobalization and slowbalization. Last but not least important is the problem of the increasingly dangerous process of uneven distribution of wealth in the world. This is the domain of development economics, whose postulates have long proved ineffective. Moreover, it is right now when there appears a chance to take a closer look at the mechanism of rotation of metropolises and peripheries. 
We realize that they we barely hint at the need to modernize the contents and methods of economic sciences. It seems that the pandemic crisis is the last straw that breaks the camel's back - a camel that already bears ignorance and hypocrisy - and it also is a motivating factor to intensify cognitive efforts. We deem it preferable to begin with an inventory of achievements, deficiencies, and new ideas of economic sciences.

Finally, we recognize that our analysis above is not free from numerous limitations. First, some of the issues raised have been stirring the emotions of scientists, intellectuals, and journalists for a long time, and it is not certain whether the Covid-19 pandemic will change their attitude, which seems to be the sine qua non condition for change. Second, the list of issues for modification/revision is much longer than the one presented above, and we hope that it will be expanded by others, encouraged to participate in the discussion we propose. Third, paradoxically, the magnitude of potential changes both in real economic life and in science, including economic sciences - can be expected to be proportional to the duration of the pandemic. The relatively rapid containment of the pandemic seems to foster the eventual undertaking of relatively minor adjustments to economic sciences, while its prolonged duration may trigger more radical transformations in how economic sciences perform its descriptive, explanatory, and normative functions.

We are aware that not all important problems have been discussed and that the presented descriptions of the indicated problems are selective in nature and are based on the experience and views of the authors (i.e. an intuitive component appears) and on exemplary literature sources only (which does not exhaust the existing achievements). These circumstances indicate the justification of the extensive reflection and discussion on the modification of the economic sciences paradigm postulated by the authors.

\section{REFERENCES}

Al-Rodhan, N.R.F. \& Stoudmann, G. (2006). Definitions of Globalization: A Comprehensive Overview and a Proposed Definition. Geneva: Geneva Center for Security Policy. Retrieved from https://citeseerx.ist.psu.edu/viewdoc/download?doi=10.1.1.472.4772\&rep=rep1\&type=pdf on May 25, 2021.

Banaszyk, P., Deszczyński P., Gorynia, M., \& Malaga K. (2021). Przesłanki modyfikacji wybranych koncepcji ekonomicznych na skutek pandemii COVID-19. Gospodarka Narodowa. The Polish Journal of Economics, 1(305), 53-86. http://doi.org/10.33119/GN/132485

Becker, G.S. (1976). The Economic Approach to Human Behavior. Chicago: University of Chicago Press. http://doi.org/10.1080/00207543.2011.563826

Bhagwati, J. (2004). In defence of globalization. Oxford: Oxford University Press. http://doi.org/10.2307/40204318

Bharma R., Dani, S., \& Burnard, K. (2011). Resilience: the concept, a literature review and future directions. International Journal of Production Research, 49(18), 195-211. http://doi.org/10.1080/00207543.2011.563826

Boushey, H., Delong, J.B., \& Steinbaum, M. (Eds.) (2017). After Piketty: The Agenda for Economics and Inequality. Cambridge, MA: Harvard University Press.

Brilman, J. (2004). Les meilleures pratiques de management. Paris: Editions d'Organisation.

Caligiuri, P., De Cieri, H., Minbaeva, D., Verbeke, A., \& Zimmermann, A. (2020). International HRM insights for navigating the Covid-19 pandemic: Implications for future research and practice. Journal of International Business Studies, 51(5), 697-713. http://doi.org/10.1057/s41267-020-00335-9.

Colander, D., Hold R.P.F., \& Barkley, J. (2003). The Changing Face of Mainstream Economics (Middlebury College Economics Discussion Paper No. 03-27). Retrieved from http://www.middlebury.edu/ econ on November 16, 2020.

Coyle, D. (2020). Markets, State, and People: Economics for Public Policy. Princeton: Princeton University Press.

D'Aveni, R. (1995). Coping with Hypercompetition: Utilizing the New 7S's Framework. Academy of Management Executive 9(3), 45-57. http://doi.org/10.5465/ame.1995.9509210281

Daly, H. \& Cobb, J.B. Jr (1989). For the Common Good: Redirecting the Economy toward Community, the Environment and a Sustainable Future. Boston: Beacon Press. http://doi.org/10.1177/027046769101100137

Davis, J. (2006). The Turn in Economics: Neoclassical Dominance to Mainstream Pluralism. Journal of Institutional Economics, 2(1), 1-20. http://doi.org/10.1017/S1744137405000263. 
Deszczyński P. (2011). Conceptualization of globalization. In P. Deszczyński (Ed.), Globalization. Poznań: WSB University Press.

Dzionek-Kozłowska, J. (2018). Model homo economicus. Geneza, ewolucja, wpływ na rzeczywistość gospodarczq. Łódź: Wydawnictwo Uniwersytetu Łódzkiego.

The Economist. (2020, July 25). Starting over again - The covid-19 pandemic is forcing a rethink in macroeconomics, Briefing, No 25., 13-16.

Fiedor, B. (2019). Podział na ortodoksję i heterodoksję w świetle potrzeby pluralizmu metodologicznego w ekonomii, perspektywa mikroekonomiczna. In M. Gorynia (Ed.), Ewolucja nauk ekonomicznych. Jedność a różnorodność. Relacje do innych nauk. Problemy klasyfikacyjne (pp. 41-56). Warszawa: Polska Akademia Nauk, Komitet Nauk Ekonomicznych.

Friedman, M. (1953). Essays in Positive Economics. Chicago: Chicago University Press.

Gorynia, M. (2019a). Współczesne nauki ekonomiczne - tożsamość, ewolucja, klasyfikacje. In M. Gorynia (Ed.), Ewolucja nauk ekonomicznych. Jedność a różnorodność. Relacje do innych nauk. Problemy klasyfikacyjne (pp. 13-14). Warszawa: Polska Akademia Nauk. http://doi.org/10.12775/EiP.2020.014.

Gorynia, M. (2019b). Competition and Globalisation in Economic Sciences: Selected Aspects. Economics and Business Review, 5(3), 118-133. http://doi.org/10.18559/ebr.2019.3.7

Gorynia, M. (2021). Will COVID-19 Kill Globalization? In M.A. Marinov \& S.T. Marinova (Eds.), Covid-19 and International Business. Change of Era (pp. 66-73). London: Routledge. http://doi.org/10.4324/9781003108924

Hall, Ch.A.S. \& Day, J. W. Jr. (2009). Revisiting the Limits to Growth after Peak Oil. American Scientist, 97(3), 230237. http://doi.org/10.1511/2009.78.230

Herma-Fox, A., LaPerla, B., Serafeim, G., \& Wang, H. (2020). Corporate Resilience and Response During Covid-19. Retrieved from https://www.top1000funds.com/wp-content/uploads/2020/04/Corporate-Resilience-andResponse-during-Covid-19_April-20.pdf on April 11, 2021.

Hume, D. (1969). A Treatise of Human Nature. Oxford: Clarendon Press.

Kowalski, T. (2013). Globalization and transformation in Central European countries: The case of Poland. Poznań: Poznań University of Economics Press.

Krugman, P. (2020). Arguing with Zombies: Economics, Politics, and the Fight for a Better Future. New York: W.W. Norton \& Company.

Manyika J., Pinkus G., \& Tiun M. (2020). Rethinking the Future of American Capitalism (McKinsey Global Institute). Retrieved from https://www.mckinsey.com/ /media/McKinsey/Featured Insights/Long term Capitalism/Rethinking the future of American capitalism/Rethinking-the-future-of-American-capitalism.pdf?shouldIndex=false on November 12, 2020.

McKinsey Global Institute (2021). Retrieved from: https://www.mckinsey.com/ /media/McKinsey/Featured\%20Insights/Long\%20term\%20Capitalism/Rethinking\%20the\%20future\%20of\%20American\%20capitalism/Rethinking-the-future-of-American-capitalism.pdf?shouldIndex=false on April 12, 2021.

Neely, A. (1999). The performance measurement revolution: why now and why next. International Journal of Operations and Production Management, 19(2), 205-228. http://doi.org/10.1108/01443579910247437.

North, D.C. (1990). Institutions, Institutional Change and Economic Performance. Cambridge: Cambridge University Press. http://doi.org/10.1017/CBO9780511808678

Nozal, A.L, Martin, N., \& Murtin, F. (2019). The Economy of Well-being: Creating Opportunities for People's Wellbeing and Economic growth. Retrieved from https://www.oecd.org/officialdocuments/publicdisplaydocumentpdf/?cote=SDD/DOC(2019)2\&docLanguage=En on May 27, 2021.

Popper, K.R. (1963). Conjectures and Refutations: The Growth of Scientific Knowledge. London: Routledge \& K. Paul.

Robbins, L. (1932). An Essay on the Nature and Significance of Economic Science. London: Macmillan.

Rodrik, D. (2011). The Globalization Paradox: Democracy and the Future of the World Economy. New York: Norton and Company.

Rodrik, D. (2015). Economics rules: Why economics works, when it fails, and how to tell the difference. Oxford: Oxford University Press.

Rodrik, D. (2017). Populism and the Economics of Globalization. Paper presented at AIB Conference - Dubai. Retrieved from https://drodrik.scholar.harvard.edu/files/dani-rodrik/files/populism_and_the_economics_of_globalization.pdf on March 22, 2021. 
Roubini, N. (2020a, July 29). Revisiting the White Swans. Project Syndicate. Retrieved from https://www.projectsyndicate.org/commentary/global-tail-risks-remain-a-threat-in-2020-by-nouriel-roubini-2020-07?barrier=accesspaylog on March 22, 2021.

Roubini, N. (2020b, March 24). A Greater Depression? Project Syndicate. Retrieved from https://www.projectsyndicate.org/commentary/coronavirus-greater-great-depression-by-nouriel-roubini-2020-03?barrier=accesspaylog on March 22, 2021.

Sandbu, M. (2020). The Economics of Belonging: A Radical Plan to Win Back the Left Behind and Achieve Prosperity for All. Princeton: Princeton University Press.

Serra, N. \& Stiglitz, J. E. (Eds.) (2008). The Washington Consensus Reconsidered: Toward a New Global Governance. Oxford: Oxford University Press. http://doi.org/10.1093/acprof:oso/9780199534081.001.0001.

Skidelsky, R. (2020). What's Wrong with Economics? A Primer for the Perplexed, New Haven: Yale University Press. http://doi.org/10.12987/9780300252767.

Stiglitz, J. E. (2002). Globalization and its Discontents. Washington: W.W. Norton Company. http://doi.org/10.1046/j.0391-5026.2003.00107.x

Stiglitz, J. E., Fitoussi, J-P., \& Durand, M. (2018). Beyond GDP Measuring What Counts for Economic and Social Performance. Paris: OECD Publishing. http://doi.org/10.1787/9789264307292-en.

Stiglitz, J. E., Sen, A., \& Fitoussi, J-P. (2009). Report by the Commission on the Measurement of Economic Performance and Social Progress. Retrieved from http//www.stiglitz-sen-fitoussi.fr on March 03, 2021.

Street, J. (1987). The Institutional Theory of Economic Development. Journal of Economic Issues 21(4), 1861-1887. Retrieved from https://www.jstor.org/stable/4225949?seq=1\#metadata_info_tab_contents on May 31, 2021.

Streeten, P. (2001). Globalisation: Threat or opportunity?. Copenhagen: Copenhagen Business School Press. http://doi.org/10.4236/jmp.2016.74039.

Taleb, N.N. (2010). The Black Swan: The Impact of the Highly Improbable. New York: Random House Trade.

Van der Bergh, J. \& Antal, M. (2011). Evaluating alternatives to GDP as measures of social welfare/progress. Retrieved from: https://www.wifo.ac.at/bibliothek/archiv/36247/WWWforEurope_WP_056.pdf. on December 12, 2020.

Varshney, L.R., \& Socher, R. (2020), COVID-19 Growth Rate decreases with Social Capital, Retrieved from https://www.medrxiv.org/content/10.1101/2020.04.23.20077321v1.full.pdf on May 27, 2021.

Wolf, M. (2020, July 16). How Covid-19 will change the world? Financial Times. Retrieved from https://www.ft.com/content/9b8223bb-c5e4-4c11-944d-94ff5d33a909 on September 2, 2020.

Yadav, N., Sushil, N., \& Sagar, M. (2013). Performance Measurement and Management Frameworks: Research Trends of the Last Two Decades. Business Process Management Journal, 19(6), 947-971. http://doi.org/10.1108/BPMJ-01-2013-0003 


\section{Authors}

The contribution share of authors is equal and amounted to $25 \%$ for each of them.

\section{Piotr Banaszyk}

PhD in Economics (1989, Poznań University of Economics and Business, Poland); Professor at Poznań University of Economics and Business (Poland). His research interests include international supply chain management and strategic management.

Correspondence to: Prof. Piotr Banaszyk, PhD, Poznań University of Economics and Business, al. Niepodległości, 10,61-875 Poznań, e-mail: piotr.banaszyk@ue.poznan.pl

ORCID (i) http://orcid.org/0000-0002-9457-3613

\section{Przemysław Deszczyński}

PhD of Humanities in Political Science (1989, Adam Mickiewicz University in Poznań, Poland); Professor at Poznań University of Economics and Business (Poland). His research interests include international economics, economy of development, and information economics.

Correspondence to: Prof. Przemysław Deszczyński, PhD, Poznań University of Economics and Business, al. Niepodległości, 10, 61-875 Poznań, e-mail: przemyslaw.deszczyński@ue.poznan.pl

ORCID (1) http://orcid.org/0000-0003-2286-3395

\section{Marian Gorynia}

PhD in Economics (1985, Poznań University of Economics and Business, Poland); Professor at Poznań University of Economics and Business (Poland). His research interests include international economics and international business.

Correspondence to: Prof. Marian Gorynia, PhD, Poznań University of Economics and Business, al. Niepodległości, 10, 61-875 Poznań, e-mail: marian.gorynia@ue.poznan.pl

ORCID (1) http://orcid.org/0000-0002-7633-8249

\section{Krzysztof Malaga}

PhD in Economics (1990, Poznań University of Economics and Business, Poland); Professor at Poznań University of Economics and Business (Poland). His research interests include economic growth and development, microeconomics, macroeconomics.

Correspondence to: Prof. Krzysztof Malaga, PhD, Poznań University of Economics and Business, al. Niepodległości, 10, 61-875 Poznań, e-mail: krzysztof.malaga@ue.poznan.pl

ORCID (1) http://orcid.org/0000-0001-7079-9880

\section{Acknowledgements and Financial Disclosure}

This publication refers to the article by Banaszyk, Deszczyński, Gorynia, \& Malaga (2021) and it uses modified selected fragments of this text. The authors would like to thank the anonymous referees for their useful comments, which allowed to increase the value of this article.

\section{Conflict of Interest}

The authors declare that the research was conducted in the absence of any commercial or financial relationships that could be construed as a potential conflict of interest.

\section{Copyright and License}

This article is published under the terms of the Creative Commons

Attribution - NoDerivs (CC BY-ND 4.0) License

http://creativecommons.org/licenses/by-nd/4.0/ 